\title{
RE-EVALUATING ENTREPRENEURIAL MARKETING DIMENSIONS IN THE PURSUIT OF SME INNOVATION AND GROWTH
}

\author{
Daniel K. Gameti \\ University of Canterbury • Christchurch, New Zealand \\ Jamie D. Collins \\ University of Canterbury $\bullet$ Christchurch, New Zealand \\ Sussie C. Morrish \\ University of Canterbury $\bullet$ Christchurch, New Zealand
}

\section{ABSTRACT}

The relevance of Entrepreneurial Marketing (EM) dimensions in firm performance has been confirmed in many studies of a wide range of firms. EM is particularly helpful in turbulent and unpredictable business environment such as the one currently presented by the Covid-19 pandemic. There is however no consensus as to which EM dimensions are the most effective at promoting firm innovation and growth. Although many studies have used the seven dimensions proposed by Morris et al. (2002), there is a growing body of literature that points to the role of other dimensions. In this paper, we propose that in addition to the seven established dimensions, Internal Marketing Practices (IMP) can help improve our understanding of how entrepreneurial firms can achieve improved innovation and growth.

KeyWords: Entrepreneurial Marketing Dimensions, SMEs, Innovation, Growth, Internal Marketing Practice

\section{INTRODUCTION}

The Entrepreneurial Marketing (EM) concept has made a significant impact on our understanding of the performance of both small and large firms (Eggers et al., 2020; Morrish, 2011; Solé \& Jones, 2013). For example, Small and Medium-Size Enterprises (SMEs) are found to benefit more from EM than their large counterparts due to their limited resources, lack of marketing knowledge and informal approach to doing business (Franco et al., 2014; Gilmore, 2011; Jones \& Rowley, 2011; Morrish, Miles \& Deacon, 2010). While there are a number of EM definitions, one that is widely adapted in many studies is that of (Morris, Schindehutte \& LaForge, (2002, p. 5) that defines EM as “.... the proactive identification and exploitation of 
opportunities for acquiring and retaining profitable customers through innovative approaches to risk management, resource leveraging and value creation".

Unlike conventional marketing practices that emphasize the satisfaction of customers' current needs and wants (Carson \& Gilmore, 2000) EM is aimed at satisfying customers' current and latent needs (Chesbrough, 2010) by integrating entrepreneurial orientation and market orientation for the benefits of firms, particularly SMEs (Franco et al., 2014). Morris et al. (2002) proposed seven EM dimensions: proactiveness, opportunity focused, innovativeness, risk taking, customer centric, resource leveraging and value creation. These dimensions have been used extensively to measure firm performance with different outcomes. Although not all the dimensions were found significant in all studies, there is sufficient evidence to suggest that all the dimensions are relevant in achieving satisfactory SME performance (Becherer, Helms, \& McDonald, 2012; Sadiku-Dushi, Dana, \& Ramadani, 2019). However, it is important to re-evaluate these dimensions and their impact on other aspects of business performance. The objective of this paper is to consider another potential dimension of EM that could influence SME innovation and growth.

The contribution of SMEs to the economy cannot be overemphasized. Across the world, they contribute to national income, job creation, poverty reduction, economic growth and reduction in social problems (Baas \& Schrooten, 2006; Oduro $\&$ Nyarku, 2018; OECD, 2010). It is for these reasons that SMEs need to innovate and grow. Hence the need to find ways to enhance SME innovation capability and growth (Bamiatzi \& Kirchmaier, 2014; Collins \& Reutzel, 2017; Kahn, 2018). Lam $\&$ Harker $(2015$, p. 341) suggest that "if entrepreneurship is the soul of a business, marketing is the flesh". Therefore, entrepreneurship and marketing complement each other and EM influences SME performance (Franco et al., 2014; Gilmore, 2011).

One marketing dimension that none of the EM studies have yet considered is Internal Marketing Practice (IMP). IMP is a concept that emphasizes the important role of employees and the need to treat them as internal customers (Berry, 1981; Debra \& Lacono, 2015; Sasser \& Arbeit, 1976). This is because, when employees (internal customers) are satisfied through effective IMP, external customer intensity which is a key dimension of EM will be enhanced (George, 1990). Furthermore, employee retention is a challenge to most SMEs (Morrish, 2009). Given this argument, it is important that IMP be explored as a potential dimension of EM. This paper argues that beyond the seven EM dimensions proposed by Morris et al. (2002), IMP should be adopted as a necessary dimension in order for firms to innovate and grow. 


\section{WHAT IS ENTREPRENEURIAL MARKETING?}

Since its inception, EM has received considerable attention (Hills et al., 2008) from scholars in different business disciplines. Researchers however believe that the concept is yet to find its grounding as a research domain (Alqahtani \& Uslay, 2020). This is because a majority of the literature is found in entrepreneurship journals (Hansen \& Eggers, 2010). EM has been described as marketing with an entrepreneurial mindset and today, many marketing journals have published EM papers (Yadav \& Bansal, 2020). One thing that is certain is that a number of experts agree that EM is the interface between entrepreneurship and marketing (Morris et al., 2002) that leads firms to achieve competitive advantage (Hills et al., 2008; Morrish et al., 2010). Like the proverbial elephant, different authors have defined EM based on which dimensions have been investigated. Following their seminal work in 2002, many researchers have used the definition of Morris et al. (2002) as a starting point, out of which the famous seven dimensions were derived. To provide information on the different perspectives, Table 1 presents various definitions of EM. Although the list may not cover all the available definitions in literature, it provides various 'lenses' in looking at the EM construct.

Table 1

\section{Definitions of EM}

\begin{tabular}{|l|l|}
\hline Author (Year) & Definition \\
\hline Morris et al (2002 p. 5) & $\begin{array}{l}\text { "EM is the proactive identification and exploitation of } \\
\text { opportunities for acquiring and retaining profitable customers } \\
\text { through innovative approaches, to risk management, resource } \\
\text { leveraging and value creation" }\end{array}$ \\
\hline $\begin{array}{l}\text { Bjerke and Hultman } \\
(2004, \text { p. 15) }\end{array}$ & $\begin{array}{l}\text { "EM is the marketing of small firms growing through } \\
\text { entrepreneurship" }\end{array}$ \\
$\begin{array}{l}\text { Four themes relevant to understanding entrepreneurial marketing } \\
\text { within social enterprise context emerged: opportunity recognition } \\
\text { (OR); entrepreneurial effort (EE); an entrepreneurial } \\
\text { organizational culture (EOC) and networks and networking." }\end{array}$ \\
\hline $\begin{array}{l}\text { Bäckbro and Nyström } \\
\text { (2006, p. 13) }\end{array}$ & $\begin{array}{l}\text { "EM is the overlapping aspect between marketing and } \\
\text { entrepreneurship; therefore, it is the behavior shown by any } \\
\text { individual and/or organization that attempt to establish and } \\
\text { promote market ideas, while developing new ones in order to } \\
\text { create value." }\end{array}$ \\
\hline
\end{tabular}




\begin{tabular}{|c|c|}
\hline Kraus et al. $(2010$, p. 9$)$ & $\begin{array}{l}\text { "EM is an organisational function and set of processes for } \\
\text { creating, communicating and delivering value to customers and } \\
\text { for managing customer relationships in ways that benefit the } \\
\text { organisation and its stakeholders, and that is characterised by } \\
\text { innovativeness, risk-taking, proactiveness, and may be performed } \\
\text { without resources currently controlled" }\end{array}$ \\
\hline $\begin{array}{l}\text { Hills and Hultman } \\
(2011, \text { p. } 6)\end{array}$ & $\begin{array}{l}\text { "EM is a spirit, an orientation as well as a process passionately } \\
\text { pursuing opportunities and launching and growing ventures that } \\
\text { create perceived customer value through relationships by } \\
\text { employing innovativeness, creativity, selling, market immersion, } \\
\text { networking and flexibility." }\end{array}$ \\
\hline $\begin{array}{l}\text { Ionita and Marketing } \\
(2012, \text { p. } 7)\end{array}$ & $\begin{array}{l}\text { "EM is a set of processes of creating, communicating and } \\
\text { delivering value, guided by effectuation logic and used in a highly } \\
\text { uncertain business environment" }\end{array}$ \\
\hline $\begin{array}{l}\text { Becherer et al. (2012, } \\
\text { p.7) }\end{array}$ & $\begin{array}{l}\text { "EM is the marketing processes of firms pursuing opportunities in } \\
\text { uncertain market circumstances often under constrained resource } \\
\text { conditions." }\end{array}$ \\
\hline $\begin{array}{l}\text { Whalen et al. (2016, } \\
\text { p.3) }\end{array}$ & $\begin{array}{l}\text { "EM is a combination of innovative, proactive, and risk-taking } \\
\text { activities that create, communicate, and deliver value to and by } \\
\text { customers, entrepreneurs, marketers, their partners, and society at } \\
\text { large." }\end{array}$ \\
\hline $\begin{array}{l}\text { Pane Haden et al. } \\
(2016, \text { p. } 122)\end{array}$ & $\begin{array}{l}\text { "EM is the process of opportunity discovery, opportunity } \\
\text { exploitation and value creation that is carried out by an individual } \\
\text { who often exhibits a proactive orientation, innovation focus and } \\
\text { customer intensity and is able to leverage relationships and } \\
\text { resources and manage risk". }\end{array}$ \\
\hline $\begin{array}{l}\text { Morrish and Jones } \\
(2020, \text { p.90) }\end{array}$ & $\begin{array}{l}\text { "EM is a configuration of activities that emerge from entrepreneur } \\
\text { decision and actions for pursuing business objectives in stable and } \\
\text { turbulent environments that incorporate opportunity-seeking, } \\
\text { resource-organising and risk-accepting behavior to create multiple } \\
\text { stakeholder value." }\end{array}$ \\
\hline $\begin{array}{l}\text { Alqahtani and Uslay } \\
(2020 \text { p.64) }\end{array}$ & $\begin{array}{l}\text { "EM is an agile mindset that pragmatically leverages resources, } \\
\text { employs networks and takes acceptable risks to proactively exploit } \\
\text { opportunities for innovative co-creation, and delivery of value to } \\
\text { stakeholders, including customers, employees, and platform } \\
\text { allies". }\end{array}$ \\
\hline
\end{tabular}

Source: Adapted and extended from Alqahtani and Uslay (2020) Sadiku-Dushi et al. (2019) and Sole (2013) 


\section{EM DIMENSIONS}

To date, there is no consensus on the number of dimensions that constitute EM (Kilenthong, Hultman, \& Hills, 2016; Sadiku-Dushi et al., 2019). This is evident in studies that have used different dimensions in measuring EM. This inconsistency notwithstanding, a number of studies have used some or all (Becherer et al., 2012; Crick, 2019; Hacioglu et al., 2012; Morrish \& Deacon, 2011; Rashad, 2018; SadikuDushi et al., 2019) seven dimensions proposed by Morris et al., (2002) to empirically investigate EM practices of firms. These dimensions include proactiveness, opportunity focus, innovativeness, risk taking, resource leveraging, customer intensity and value creation. It must be noted that other researchers have used their own conceptualization of different dimensions either based on their conceptual understanding or empirical studies.

EM research typically focuses on the entrepreneur and the external customer with little or no reference to internal customers (i.e. employees). Meanwhile, all entrepreneurial ideas are implemented through employees and customer satisfaction is achieved through internal customers (Berry, 1981). We argue herein that IMP is a critical potential addition to the literature in terms of enhancing the power of EMfocused research. The existing and proposed dimensions of EM are discussed in more detail as follows.

\section{Proactiveness}

This dimension of the EM construct suggests that SMEs must not wait for customers to demand products and services before taking the steps to create products and services for them (Crick, 2019). In fact, this is one of the characteristics that distinguishes traditional marketing from EM. While traditional marketing emphasizes the identification of customer needs and wants to enable firms to create goods and services to satisfy those needs, EM looks beyond the current needs of customers to proactively design and create goods and services to satisfy not only their current needs but also their latent needs (Chesbrough, 2010). Proactiveness is a tool in achieving competitive advantage (Eggers et al., 2013). To reduce vulnerability to external environments, SMEs must take proactive steps to avoid the consequences of environmental turbulence (Becherer et al., 2012). As Sulistyo and Siyamtinah (2016) argue, it takes the initiative of a proactive firm to introduce a new product or service into the market. Studies have also found proactiveness as a necessary element of EM in achieving performance (Alqahtani \& Uslay, 2020; Hacioglu et al., 2012). 


\section{Opportunity Focused}

Opportunity is at the heart of entrepreneurship and a major dimension of EM because opportunity is the main driving force behind most start-ups (Block \& Sandner, 2009; Chu et al., 2011; Garcia-Cabrera, Garcia-Soto, \& Dias-Furtado, 2018). According to Morris et al. (2002) opportunity represents unnoticed market positions that serve as a source of profit and competitive advantage. Becherer et al. (2012) argued that opportunities are critical for the success of SMEs. Other studies have found that the survival of SMEs depends on their opportunity seeking and identification (Gilmore, 2011; Morrish, 2011; Morrish \& Jones, 2020). In a study of EM dimension and SME performance, Sadiku-Dushi et al. (2019) found that successful SMEs are highly opportunity focused. Mort, Weerawardena \& Liesch (2012) report that opportunity is among the four strategies of EM success. Again, opportunity is seen as very relevant in social value creation (Özdemir, 2013). Growth seeking SMEs must therefore scan their environment, identify opportunities, and mobilize available and necessary resources to take advantage of the opportunities to achieve their desired growth (Morrish et al., 2010; Scarborough \& Cornwall, 2011).

\section{Innovativeness}

Innovation according to the Oslo manual is the implementation of new or significantly improved products (goods or services), process, a new marketing method, or a new organizational method in business practices, workplace organization or external relation (OECD, 2005). In the entrepreneurship literature, innovation, risk management and opportunity are considered as critical success factors of any entrepreneurial activity (Miles et al., 2015).

Innovation is a capability that SMEs need to achieve sustainable growth. However, we argue that innovation is a result of innovative mindset. Moreover, firms adopting EM are encouraged to be innovative (Morris et al., 2002). Innovation may be deemed as a mindset, a process or outcome (Kahn, 2018). In this context, SMEs are expected to have innovative mindset which is different from innovation as a process or outcome. Therefore, SMEs utilizing an EM orientation should be more successful in implementing different types of innovation (implementation of new ideas) (Bachmann, Ohilies \& Flatten, 2021)

\section{Risk Taking}

This refers to SMEs taking the courage to introduce product and services to the market and pursuing market opportunities even without full awareness of what the 
outcome will be (Morris et al., 2002). Entrepreneurial capability has been measured in prior research by a firm's ability to take risk (Sulistyo \& Siyamtinah, 2016). Eggers et al. (2020) found that risk taking is among the three major dimensions that explain EM besides change-driving and bootstrapping. Entrepreneurial marketers must take calculated risks and be willing to accept some level of risk (Morrish \& Jones, 2020; Scarborough \& Cornwall, 2011) to achieve results. Although entrepreneurs are risk takers, they also take steps to mitigate the potential negative effect of the risk they take (Morrish et al., 2010) in order not to be devastated when things go wrong; a situation described as affordable loss (Sarasvathy, 2001).

\section{Resource Leveraging}

Leveraging refers to achieving more with less (Morris et al., 2002). One of the major challenges confronting SMEs is resource constraints (Becherer et al., 2012; Ionitã, 2012) and to address this, EM firms need to leverage their resources to achieve maximum result from limited resources available (Yadav \& Bansal, 2020). As Morris et al. (2002) pointed out, firms can maximize their resources by borrowing, leasing, bartering, sharing, contracting, or outsourcing required resources. SMEs may sometimes collaborate with their competitors to use the same resource for mutual benefit (Anwar \& Daniel, 2016; Crick, 2019) and discover a source not seen by others (Becherer et al., 2012). Resource leveraging is therefore an important dimension of EM in achieving performance among SMEs.

\section{Customer Intensity}

Although Morris et al. (2002) refers to customer intensity as a dimension of the EM construct, customers are probably the pivot around which every business, whether for profit or non-profit, revolves (Kohli \& Jaworski, 1990; Narver \& Slater, 1990). In today's competitive business environment, where customers have become sophisticated and dictate the pace of every business activity, it will be remiss for any business to ignore the customer in their business decisions. The relevance of customer intensity as a dimension of EM cannot be overemphasized. Several studies that have used customer intensity as an EM dimension have found significant positive relationship between customer intensity and firm performance (Becherer et al., 2012; Hacioglu et al., 2012; Morrish \& Deacon, 2011; Sadiku-Dushi et al., 2019) therefore, customer centric approach to marketing is an important dimension of EM. This is also confirmed by Morrish et al. (2010) who argue that EM is both entrepreneur- and customer-centric. 


\section{Value Creation}

Value creation is one of the most important factors in to every firm's survival and success. This is because the intent of every dimension discussed above is to create value for customers. Marketing is about an exchange of values (Kotler \& Keller, 2009). Customers want to exchange their resources with value from the firm. Therefore, customers will always consider the benefit derived from a product or service and juxtapose that with the cost of acquiring it to determine the value (Kotler $\&$ Keller, 2009). If the benefit derived from the product or service is equal or higher than the cost of the product, value is deemed to be created but if the cost of acquiring the product or service is higher than the benefit, customers are not likely to patronize it because value is not created. Thus, it is understandable that numerous prior studies have found value creation is an important dimension of EM (Alqahtani \& Uslay, 2020; Hills et al., 2008; Morrish \& Jones, 2020).

\section{Internal Marketing Practice}

EM is seen as the interface between entrepreneurship and marketing (Morris et al., 2002). The literature on EM has placed much emphasis on the entrepreneur (entrepreneurial orientation) and the customer (market /customer orientation) with little or no emphasis on employees. Morrish et al. (2010) argued that EM is not partly entrepreneurship and partly marketing but wholly entrepreneur-centric and customer-centric. They suggested four dynamic forces of EM namely: 1. The entrepreneur and customer as equally important actors at the organization's core; 2. Marketing and entrepreneurial business orientations as culture within the firm; 3 . EM as a collection of strategy and processes; and 4. EM shaped by the marketing mix (Morrish et al., 2010, p. 308). While these suggestions acknowledge key elements, the role of employees has not been fully considered. The customer-centric approach in marketing has often focused on external customers with very little attention to the role of internal customers (e.g. employees).

A few studies have acknowledged the importance of employees as a key resource (Morris et al., 2002; Morrish et al., 2010) in achieving organizational objectives but the EM literature has so far not considered the satisfaction of the internal customer as a critical dimension in achieving EM objectives. Debra and Lacono (2015, p. 561) define internal customers as "individuals who act on behalf of the firm, such as board members, executives, managers and employees who directly benefit through financial and socio-psychological value from their contributions to the firm's value co-creation process." Internal customers may therefore refer to all those 
who support the organization internally to achieve its objectives but are not owners of the organisation. The concept of treating employees as internal customers was first proposed by Sasser and Arbeit (1976) but gained popularity following the work of Berry (1981) who put forward that employees should be considered as customers and their jobs as products. This view is supported by several studies that echoed the importance of satisfying the needs of internal customers who intend to satisfy the needs of external customers (George, 1990; George \& Gronroos, 1989; Gronroos, 1985; Gummesson, 1987; Lukas \& Maignan, 1996). The focus on employees as internal customers is referred to as Internal Marketing (IM) in the marketing literature (Berry, 1981). This concept was originally attributed to service organisations but there is abundant evidence in the literature showing that the concept of IM is applicable to all organisations including manufacturing firms (Ahmed, Rafiq \& Saad, 2003; Ajayi, Odusanya \& Morton, 2017 ; Al-Dmour, Al-Jweinat \& Abu ElSamen, 2012; Kaur \& Sharma, 2015; Wu, Tsai \& Fu, 2013).

Berry and Parasuraman (1991, p. 151) defined IM as '.....attracting, motivating and retaining qualified employees through job products that satisfy their needs.' Winter (1985) sees it as aligning, educating, and motivating staff towards institutional objectives. It is also defined as "intra-organisational marketing of goods and services in order to carry out the firm's objectives and ultimately improves customer satisfaction" (Collins \& Payne, 1991, p. 269). The objective of implementing IM is therefore to engage employees which has its root in human resource management (Collins \& Payne, 1991; Lee \& Wen-Jung, 2005). The genesis of Employee Engagement (EE) is attributed to the work of Kahn (1990, p. 694) who defined the concept as “...harnessing of organizational members' selves to their work roles; in engagement, people employ and express themselves physically, cognitively, and emotionally during role performances". That is why George and Gronroos (1989) state that IM is a philosophy for managing an organisation's human resources based on marketing perspective. In line with IM, Kumar and Sia (2012) argue that EE improves employee and organizational performance. They linked EE to organizational profitability, low employee turnover, business growth and bottomline success. Employee engagement inspires employees to become advocates for the organization, enhances employees' faith in the organization, fosters sense of loyalty, creates a high-energy working environment, develops emotional connection with the organization, impacts employees' attitude towards clients and prepares employees to become effective brand ambassadors for the company (Kumar \& Sia, 2012).

The essence of IM is to satisfy the needs of employees first to make them capable of satisfying external customers (Bennett \& Barkensjo, 2005). In the 
definition of EM, Morris et al. (2002) emphasized acquisition and retention of customers through entrepreneurial and marketing orientations. If employees are the best asset of any organisation, it is equally important to recruit and retain them through effective human resource policies (Gronroos, 1990; Wu et al., 2013). This is in support of Gronroos (1985) who pointed out that external customer orientation is at the heart of internal customer orientation because satisfying the needs of internal customers motivate them to satisfy the needs of external customers. This is aptly demonstrated by the service-profit chain model developed by Heskett et al. (1994). They argued that, internal marketing drives employee satisfaction which drives employee productivity which drives value delivery to customers which drives customer satisfaction and eventually drives profitability through customer loyalty (Heskett et al., 1994).

IMP therefore goes beyond acknowledging employees as a resource that can be leveraged in achieving entrepreneurs' business goals (Morrish, 2009). It encapsulates among other things, training and development of employees, effective internal communication, appraisal and feedback, employee motivation, customer orientation and satisfaction, inter-functional co-ordination and integration, and management support (Kanyurhi \& Bugandwa Mungu Akonkwa, 2016). In other words, employees cannot just be used as tools in achieving EM objectives but must be seen as integral part of the EM dimensions in achieving organizational objectives (Debra \& Lacono, 2015). IM employs marketing-like tools and activities in treating employees as customers to achieve desired outcomes (Ahmed et al., 2003; Gronroos, 1985). Acknowledging the importance of IM, Kotler and Keller (2009) assert that a holistic marketing constitutes four components including relationship marketing, integrated marketing, internal marketing and social responsibility marketing. From this perspective we can say that EM cannot be complete without the practice of IM. Another reason why the implementation of IM is important particularly for SME is the fact that some entrepreneurs complain about employees' retention being a major challenge to their businesses. This is probably because the visions of entrepreneurs are achieved through employees (Morrish, 2009) therefore without engaging these employees through effective IM practice, they may exit the business at the time that they are needed most. Furthermore, Wallace and Trinka (2006) noted in Mani (2011) that, implementation of IM helps employees to be engaged during hard economic conditions and turbulent times. This is particularly relevant because EM is also found to be useful in unstable business environments (Eggers \& Kraus, 2011; Morrish, 2009; Yadav \& Bansal, 2020).

Many scholars that have contributed to the EM literature agree with Vargo and Lusch (2010) that customers are value co-creators and value beneficiaries (Morris 
et al., 2002; Debra \& Lacono 2015). When the needs of employees are satisfied and they create value for external customers, they become beneficiaries of value for having not only their financial needs but also their psychological and emotional needs satisfied (Kahn, 1990). Employees are usually used for delivering value but when well engaged, employees can also patronize the services of the organisation and serve as advocates just as the external customers do (Debra \& Lacono, 2015). IMP is therefore as important as customer intensity in the EM dimensions. Conduit and Mavondo (2001) also argue that internal customer orientation is important for the development of market orientation. Based on these collective arguments, it is therefore reasonable to conclude that holistic EM is entrepreneur-centric, internal-customer-centric and external-customer-centric. IMP should therefore be considered as an additional EM dimension. Doing so should provide researchers a more comprehensive way to assess the impact of entrepreneurial marketing on the innovation and growth of SMEs.

\section{EM DIMENSIONS, ANTECEDENTS OF SME INNOVATION AND SME GROWTH}

\section{Innovation}

In today's competitive business environment, innovation has become an indispensable resource in every organisation's toolbox. In this section the concept of innovation as a business capability is explored to provide theoretical basis for innovation as an outcome of EM dimensions. According to McCormick and Maalu (2011) cited in Oduro and Nyarku (2018, p. 12) innovation constitutes "product or process, continuous or discontinuous, radical or incremental innovations leading to improved or new products." Again, following an extensive literature review of 60 definitions of innovation, Baregheh, Rowley \& Sambrook (2009, p. 1334) concluded that innovation is "... a multi-stage process whereby organisations transform ideas into a new/improved product, service or processes, in order to advance, compete, and differentiate themselves successfully in their marketplace". Innovation is different from creativity. While creativity is thinking something new, innovation is doing something new (Scarborough \& Cornwall, 2011). Innovation is therefore not just an idea or invention (Schumpeter, 1934) but the implementation of something new. This study adopts the definition of the Oslo manual that “...innovation is the implementation of a new or significantly improved product (good or service), or process, a new marketing method, or a new organizational method in business practices, workplace organization or external relations" (OECD, 2005, p.46). From 
the above definitions it can be observed that there are two major attributes that run across all the definitions. That is: 1 . Innovation constitutes some degree of novelty (newness) and 2. Innovation aims at delivering value.

It must be noted that although innovativeness is considered as an important dimension of EM (Morris et al., 2002), this conceptualization is different from innovation as a capability. While innovation is considered as one of the dimensions of EO (Morris et al, 2002) Collins and Reutzel (2017) found that EO is not enough when considering firm investments in innovation. Investment in innovation by top management of SMEs is influenced among other things by the attractiveness of the innovation opportunity and the value to be derived from the investment (Collins \& Reutzel, 2017). Innovation is also categorized as an outcome, a process or a mindset (Kahn, 2018). Innovativeness is a mindset which refers to the internalization of innovation among all the members of the organization as a culture to achieve stipulated objectives. This is what innovativeness as a dimension of EM refers to (Morris et al., 2002). On the other hand, innovation capability is an outcome which emphasizes an output such as product, process, supply chain, marketing, organizational and business model innovations among others (Kahn, 2018). Organisations that possess innovation capabilities has a greater chance of improving their performance (Najafi-Tavani et al., 2018; Oduro \& Nyarku, 2018; Tarraço et al., 2019). Thus, innovativeness is a mindset and a culture, which can contribute to improvements in innovation performance as a process or an outcome.

\section{EM AND SME INNOVATION}

Several studies have measured the impact of EM on different outcome variables. However, very few studies have considered the effect of EM dimensions on innovation or use innovation as mediating variable in the relationship between EM and other outcome variables (Bachmann et al., 2021). This study however argues that SMEs can leverage EM dimensions to achieve innovation performance. Kocak, Carsrud \& Oflazoglu. (2017) in a study of EM and born global performance found that $\mathrm{EO}$ and $\mathrm{MO}$ positively relate to innovation and through innovation. Therefore born global firms that deploy EO and MO dimensions as a strategy will achieve global performance positively. This is confirmed by Boso, Cadogan \& Story, (2012) who found positive relationship between EMO and product innovation success. Hacioglu et al. (2012) examined the effect of firm's EM practice and firm's innovative performance and found that proactiveness, innovativeness, customer intensity and resource leveraging dimensions of EM positively influence innovation 
performance of SMEs. Whalen et al. (2015) used radical new product development as a mediating innovation capability to establish positive relationship between EM and competitive advantage. Other studies have used innovation as outcome of EM practice and innovation as mediating variables to achieve performance. (Ahmadi \& O'Cass, 2015; Arunachalam et al., 2018; Hendijani Fard \& Seyyed Amiri, 2018; Jalilvand et al., 2017; Kocak et al., 2017; Liu et al., 2017; Mansour \& Barandas, 2017; Sulistyo \& Siyamtinah, 2016). IMP has also been found as a source of competitive advantage (Karami, Jones \& Kakabadse, 2008). It enhances customer satisfaction and improves innovation and growth (Damanpour, 1991; Good \& Michel, 2013; Lin \& McDonough III, 2011; Raisch et al., 2009; Tajeddini, 2011). Jalilvand et al. (2017) in a study of internal marketing and entrepreneurial orientation on innovation found that internal marketing is a key determinant of entrepreneurial orientation and innovation in family businesses.

Measures of innovation differ among scholars. These included incremental and radical innovation (Kocak et al., 2017), the four types of innovation recommended by the Oslo manual (Dziallas \& Blind, 2019; Liu et al., 2017; Sulistyo \& Siyamtinah, 2016) new product development (Whalen et al., 2015), and business model innovation (Azari et al., 2017; Mansour \& Barandas, 2017). Recently, based on a survey data of 146 new ventures in Germany B2B sector, Bachmann et al. (2021) found significant positive relationship between EM dimensions and innovation. Their study further shows that, the effect of EM dimensions was higher on exploitative (incremental) innovation than exploratory (radical) innovation (Bachmann et al., 2021, p. 95). Although different innovation types and modes have been used as outcome of EM dimensions, there is evidence that EM dimensions including IMP influence innovation performance.

\section{$\overline{\text { EM AND SME GROWTH }}$}

Organizations, whether large or small, aim at achieving desirable levels of performance. One major performance indicator for most businesses is growth. The benefits of entrepreneurial marketing to SMEs are evident, as several studies have demonstrated the efficacy of EM dimensions on SME performance (Altinay et al., 2016; Eggers et al., 2018; Sadiku-Dushi et al., 2019; Solé \& Jones, 2013). Eggers and Kraus (2011) found that a combination of customer orientation and entrepreneurial orientation to cut operational cost as well as focus on the customer are relevant in achieving survival and growth of SMEs in hard economic conditions. Although what constitutes growth may differ across studies, the majority generally measures 
growth in terms of market share, employee growth, sales growth, financial growth, and asset growth (Altinay et al., 2016; Becherer et al., 2012; Eggers et al., 2020; Sadiku-Dushi et al., 2019). Results using these indicators however have been mixed. In a comparative study of US and UK technology firms, Jones, Suoranta \& Rowley (2013) found positive correlation between EM dimensions and growth of the firms although higher growth was achieved in US technology firms than UK technology firms. Eggers et al. (2013) examined the implications of customer orientation (CO) and entrepreneurial orientations (EO) for SME growth in Austria and reported positive relationship between EO and SME growth but negative relationship between CO and SME growth. Altinay et al. (2016) explored the interface between organizational learning capability, entrepreneurial learning, entrepreneurial orientation, and SME growth among 350 SMEs in Northern Cyprus. They found that although EO did not lead to employment growth, EO positively influence higher growth in sales and market share (Altinay et al., 2016, p. 884). In a quantitative study of 174 SMEs, Becherer et al. (2012) examined the effect of EM dimensions on outcome goals. The study found that EM dimensions either in combination or individually, positively influence the overall performance of SMEs. However, with regards to growth goals specifically, the only dimension that positively influence growth was the value creation dimension of EM (Becherer et al., 2012, p. 13). Using evidence from Social Networks, Eggers et al. (2017) explored technologies that support marketing and market development in SMEs. The result shows that EO positively relates to social network usage by SMEs and although there was no direct relationship between social networking and SME growth, social network positively mediate the relationship between EO and SME growth. In a similar study of EO and SME growth, Moreno and Casillas (2008) found indirect positive relationship between EO and SME growth. Their study shows that innovation dimension of EO made the most significance influence on SME growth (Moreno \& Casillas, 2008, p. 524). In a study of ethnic minority entrepreneurs operating online businesses in the UK, Anwar and Daniel (2016) also found positive relationship between resource leveraging dimension of EM and SME growth.

With regards to the appropriateness of considering IMP as a dimension of EM, Owusu-Frimpong and Martins (2010) found that most SMEs in Ghana do not regard employees as customers but few of them who practice IM achieved growth in terms of profitability and sales growth. Ajayi et al. (2017) examined employees' ambidexterity and employee engagement among SMEs in manufacturing and services sector in Nigeria. Their result concluded that SMEs with the appropriate organizational contexts for employee ambidexterity and employee engagement will increase their potential 
for growth and survival. In another study of employee engagement and its impact on performance, Bedarkar and Pandita (2014) argued that, organisations and their employees depend on each other therefore continuous employee engagement will positively impact on employee performance which directly affect organizational performance (Bedarkar \& Pandita, 2014). Ndubisi and Ndubisi (2013) found that sustainable IM and internal customer motivation achieved competitive advantage among SMEs in Africa. Kanyurhi and Bugandwa Mungu Akonkwa (2016) found that although there was no significant relationship between employee satisfaction and perceived organizational performance, there was significant positive relationship between internal marketing and perceived organizational performance in microfinance institutions in DR Congo. In quantitative study of 504 manufacturing and service companies, Ahmed et al. (2003) found that committed top management support as well as integrated effort towards inter-functional co-ordination are strong and critical IM factors for achieving business performance. As indicated earlier, studies on EM and SME growth have mixed results; however, the studies above clearly show that either collectively or individually, dimensions of EM including IMP have positive effect on SME growth.

\section{CONCLUSION AND RECOMMENDATION}

The objective of this study was to re-evaluate EM dimensions and how researchers go about assessing their impact on SME performance. A review of EM studies revealed that the seven dimensions of EM proposed by Morris et al. (2002) have either individually or in combination with other dimensions had significant positive effect on firm performance. Although there is no consistency in which dimensions have higher impact on firm performance, evidence from the reviews suggest that they are useful in improving performance of all businesses especially SMEs (Jones \& Rowley, 2011). This paper postulates an inclusion of IMP in the EM dimensions. Employees are integral part of every organisation's survival and success. Therefore, practicing internal marketing will go a long way in improving the performance of firms, particularly SMEs.

Literature reviewed in this paper has demonstrated mixed results when assessing the typically used EM dimensions on firm performance. We argue that researchers in the entrepreneurial marketing domain should consider IMP as an EM dimension when considering the effect on firm performance. The paper also recommends further investigation to establish the validity of IMP as a dimension of EM in addition to the other dimensions have been validated by different authors as effective scale for measuring EM (Becherer et al., 2012; Eggers et al., 2017; 
Eggers et al., 2013; Sadiku-Dushi et al., 2019). The Covid-19 pandemic has exposed many SMEs to hard and unpredictable conditions that will require the adoption of entrepreneurial marketing to survive. SMEs should embrace the multiple dimensions of EM to adapt and respond to difficult periods and ongoing competitive challenges.

\section{REFERENCES}

Ahmadi, H., \& O'Cass, A. (2015). The role of entrepreneurial marketing in new technology ventures first product commercialisation. Journal of Strategic Marketing, 24(1), 47-60.

Ahmed, P. K., Rafiq, M., \& Saad, N. M. (2003). Internal marketing and the mediating role of organisational competencies. European Journal of Marketing, 37(9), 1221-1241.

Ajayi, O. M., Odusanya, K., \& Morton, S. (2017). Stimulating employee ambidexterity and employee engagement in SMEs. Management Decision, 55(4), 662-680.

Al-Dmour, H., Al-Jweinat, H. F., \& Abu ElSamen, A. (2012). Examining the psychometric properties of internal marketing concept: scale development and validation in Jordanian manufacturing sector. Jordan Journal of Business Administration, 153(657), 1-34.

Alqahtani, N., \& Uslay, C. (2020). Entrepreneurial marketing and firm performance: Synthesis and conceptual development. Journal of Business Research, 113, 62-71. Altinay, L., Madanoglu, M., De Vita, G., Arasli, H., \& Ekinci, Y. (2016). The Interface between Organizational Learning Capability, Entrepreneurial Orientation, and SME Growth. Journal of Small Business Management, 54(3), 871-891.

Anwar, M. N., \& Daniel, E. (2016). Entrepreneurial marketing in online businesses. Qualitative Market Research: An International Journal, 19(3), 310-338.

Arunachalam, S., Ramaswami, S. N., Herrmann, P., \& Walker, D. (2018). Innovation pathway to profitability: the role of entrepreneurial orientation and marketing capabilities. Journal of the Academy of Marketing Science, 46(4), 744-766.

Azari, M. J., Madsen, T. K., \& Moen, Ø. (2017). Antecedent and outcomes of innovation-based growth strategies for exporting SMEs. Journal of Small Business and Enterprise Development, 24(4), 733-752.

Baas, T., \& Schrooten, M. (2006). Relationship Banking and SMEs: A Theoretical Analysis. Small Business Economics, 27(2/3), 127-137.

Bachmann, J.-T., Ohlies, I., \& Flatten, T. (2021). Effects of entrepreneurial marketing on new ventures' exploitative and exploratory innovation: The moderating role of competitive intensity and firm size. Industrial Marketing Management, 92, 87-100. 
Bäckbro, J., \& Nyström, H. (2006). Entrepreneurial Marketing : Innovative value creation (Publication No. Dissertation/Thesis) Högskolan i Jönköping, Internationella Handelshögskolan U6 ].

Bamiatzi, V. C., \& Kirchmaier, T. (2014). Strategies for superior performance under adverse conditions: A focus on small and medium-sized high-growth firms. International Small Business Journal, 32(3), 259-284.

Baregheh, A., Rowley, J., \& Sambrook, S. (2009). Towards a multidisciplinary definition of innovation. Management Decision, 47(8), 1323-1339.

Becherer, R. C., Helms, M. M., \& McDonald, J. P. (2012). The effect of entrepreneurial marketing on outcome goals in SMEs. New England Journal of Entrepreneurship, 15(1), 7-18.

Bedarkar, M., \& Pandita, D. (2014). A Study on the Drivers of Employee Engagement Impacting Employee Performance. Procedia, social and behavioral sciences, 133, 106-115.

Bennett, R., \& Barkensjo, A. (2005). Relationship quality, relationship marketing, and client perceptions of the levels of service quality of charitable organisations. International journal of service industry management, 16(1), 81-106.

Berry, L. L. (1981). The employee as customer. Journal of retail banking, 3(1), 3340.

Berry, L. L., \& Parasuraman, A. (1991). Marketing services: competing through quality. Free Press.

Bjerke, B., \& Hultman, C. (2004). Entrepreneurial marketing: The growth of small firms in the new economic era. Edward Elgar Publishing.

Block, J., \& Sandner, P. (2009). Necessity and opportunity entrepreneurs and their duration in self-employment: evidence from German micro data. Journal of Industry, Competition and Trade, 9(2), 117-137.

Boso, N., Cadogan, J. W., \& Story, V. M. (2012). Entrepreneurial orientation and market orientation as drivers of product innovation success: A study of exporters from a developing economy. International Small Business Journal: Researching Entrepreneurship, 31(1), 57-81.

Carson, D., \& Gilmore, A. (2000). Marketing at the Interface: Not 'What' but 'How'. Journal of Marketing Theory and Practice, 8(2), 1-7.

Chesbrough, H. (2010). Business Model Innovation: Opportunities and Barriers. Long Range Planning, 43(2-3), 354-363.

Chu, H. M., Kara, O., Zhu, X., \& Gok, K. (2011). Chinese entrepreneurs. Journal of Chinese Entrepreneurship, 3(2), 84-111. 
Collins, B., \& Payne, A. (1991). Internal marketing: A new perspective for HRM. European Management Journal, 9(3), 261-270.

Collins, J. D., \& Reutzel, C. R. (2017). The role of top managers in determining investment in innovation: The case of small and medium-sized enterprises in India. International Small Business Journal: Researching Entrepreneurship, 35(5), 618-638.

Conduit, J., \& Mavondo, F. T. (2001). How critical is internal customer orientation to market orientation? Journal of Business Research, 51(1), 11-24.

Crick, J. M. (2019). Incorporating coopetition into the entrepreneurial marketing literature. Journal of Research in Marketing and Entrepreneurship, 21(1), 1936.

Damanpour, F. (1991). Organizational innovation: A meta-analysis of effects of determinants and moderators. Academy of management journal, 34(3), 555-590.

Debra, G., \& Lacono, L. J. (2015). Value creation: an internal customers' perspective. Journal of Services Marketing, 29(6/7), 560-570.

Dziallas, M., \& Blind, K. (2019). Innovation indicators throughout the innovation process: An extensive literature analysis. Technovation, 80-81, 3-29.

Eggers, F., Hatak, I., Kraus, S., \& Niemand, T. (2017). Technologies That Support Marketing and Market Development in SMEs-Evidence from Social Networks. Journal of Small Business Management, 55(2), 270-302.

Eggers, F., \& Kraus, S. (2011). Growing Young SMEs in Hard Economic Times: The Impact of Entrepreneurial and Customer Orientations - A Qualitative Study from Silicon Valley. Journal of Small Business \& Entrepreneurship, 24(1), 99111.

Eggers, F., Kraus, S., Hughes, M., Laraway, S., \& Snycerski, S. (2013). Implications of customer and entrepreneurial orientations for SME growth. Management Decision, 51(3), 524-546.

Eggers, F., Niemand, T., Kraus, S., \& Breier, M. (2020). Developing a scale for entrepreneurial marketing: Revealing its inner frame and prediction of performance. Journal of Business Research, 113, 72-82.

Franco, M., de Fátima Santos, M., Ramalho, I., \& Nunes, C. (2014). An exploratory study of entrepreneurial marketing in SMEs. Journal of Small Business and Enterprise Development, 21(2), 265-283.

Garcia-Cabrera, A. M., Garcia-Soto, M. G., \& Dias-Furtado, J. (2018). The individual's perception of institutional environments and entrepreneurial motivation in developing economies: Evidence from Cape Verde. South African Journal of Economic and Management Sciences, 21(1), 1-18. 
George, W. R. (1990). Internal marketing and organizational behavior: A partnership in developing customer-conscious employees at every level. Journal of Business Research, 20(1), 63-70.

George, W. R., \& Gronroos, C. (1989). Developing customer-conscious employees at every level: internal marketing. Handbook of services marketing, 29-37.

Gilmore, A. (2011). Entrepreneurial and SME marketing. Journal of Research in Marketing and Entrepreneurship, 13(2), 137-145.

Good, D., \& Michel, E. J. (2013). Individual Ambidexterity: Exploring and Exploiting in Dynamic Contexts. The journal of psychology, 147(5), 435-453.

Gronroos, C. (1985). Internal marketing-theory and practice. Services Marketing in a Changing Environment, American Marketing Association, Chicago, IL, 41(7).

Gronroos, C. (1990). Relationship approach to marketing in service contexts: The marketing and organizational behavior interface. Journal of Business Research, 20(1), 3-11.

Gummesson, E. (1987). The new marketing-Developing long-term interactive relationships. Long Range Planning, 20(4), 10-20.

Hacioglu, G., Eren, S. S., Eren, M. S., \& Celikkan, H. (2012). The Effect of Entrepreneurial Marketing on Firms' Innovative Performance in Turkish SMEs. Procedia - Social and Behavioral Sciences, 58, 871-878.

Hansen, D. J., \& Eggers, F. (2010). The marketing/entrepreneurship interface: a report on the "Charleston Summit". Journal of Research in Marketing and Entrepreneurship, 12(1), 42-53.

Hendijani Fard, M., \& Seyyed Amiri, N. (2018). The effect of entrepreneurial marketing on halal food SMEs performance. Journal of Islamic Marketing, 9(3), 598-620.

Heskett, J. L., Jones, T. O., Loveman, G. W., Sasser, W. E., \& Schlesinger, L. A. (1994). Putting the service-profit chain to work. Harvard business review, 72(2), 164-174.

Hills, G. E., Hultman, C. M., Miles, M. P., Handelshögskolan vid Örebro, u., \& Örebro, u. (2008). The Evolution and Development of Entrepreneurial Marketing. Journal of Small Business Management, 46(1), 99-112.

Ionita, D. J. M., \& Marketing. (2012). Entrepreneurial marketing: A new approach for challenging times. 7(1), 131.

Jalilvand, M. R., Nasrolahi Vosta, L., Khalilakbar, R., Khazaei Pool, J., \& Tabaeeian, R. A. (2017). The Effects of Internal Marketing and Entrepreneurial Orientation on Innovation in Family Businesses. Journal of the Knowledge Economy, 10(3), 1064-1079. 
Jones, R., \& Rowley, J. (2011). Entrepreneurial marketing in small businesses: A conceptual exploration. International Small Business Journal, 29(1), 25-36.

Jones, R., Suoranta, M., \& Rowley, J. (2013). Entrepreneurial marketing: a comparative study. The Service Industries Journal, 33(7-8), 705-719.

Kahn, K. B. (2018). Understanding innovation. Business Horizons, 61(3), 453-460.

Kahn, W. A. (1990). Psychological conditions of personal engagement and disengagement at work. Academy of management journal, 33(4), 692-724.

Kanyurhi, E. B., \& Bugandwa Mungu Akonkwa, D. (2016). Internal marketing, employee job satisfaction, and perceived organizational performance in microfinance institutions. International Journal of Bank Marketing, 34(5), 773796.

Karami, A., Jones, B. M., \& Kakabadse, N. (2008). Does strategic human resource management matter in high-tech sector? Some learning points for SME managers. Corporate Governance: The international journal of business in society, 8(1), 7-17.

Kaur, J., \& Sharma, S. K. (2015). Internal Marketing: Scale Development and Validation. Vision: The Journal of Business Perspective, 19(3), 236-247.

Kilenthong, P., Hultman, C. M., \& Hills, G. E. (2016). Entrepreneurial marketing behaviours: impact of firm age, firm size and firm's founder. Journal of Research in Marketing and Entrepreneurship, 18(1), 127-145.

Kocak, A., Carsrud, A., \& Oflazoglu, S. (2017). Market, entrepreneurial, and technology orientations: impact on innovation and firm performance. Management Decision, 55(2), 248-270.

Kohli, A. K., \& Jaworski, B. J. (1990). Market Orientation: The Construct, Research Propositions, and Managerial Implications. Journal of Marketing, 54(2), 1-18.

Kotler, P., \& Keller, K. L. (2009). Marketing management (13th ed.). Pearson Prentice Hall.

Kraus, S., Harms, R., Fink, M. J. I. J. o. E., \& Management, I. (2010). Entrepreneurial marketing: moving beyond marketing in new ventures. International Journal of Entrepreneurship and Innovation Management, 11(1), 19.

Kumar, R., \& Sia, S. K. (2012). Employee Engagement: Explicating the Contribution of Work Environment. Management and Labour Studies, 37(1), 31-43.

Lam, W., \& Harker, M. J. (2015). Marketing and entrepreneurship: An integrated view from the entrepreneur's perspective. International Small Business Journal, $33(3), 321-348$. 
Lee, C., \& Wen-Jung, C. (2005). The effects of internal marketing and organizational culture on knowledge management in the information technology industry. International Journal of Management, 22(4), 661.

Lin, H.-E., \& McDonough III, E. F. (2011). Investigating the role of leadership and organizational culture in fostering innovation ambidexterity. IEEE Transactions on engineering management, 58(3), 497-509.

Liu, G., Ko, W. W. J., Ngugi, I., \& Takeda, S. (2017). Proactive entrepreneurial behaviour, market orientation, and innovation outcomes. European Journal of Marketing, 51(11/12), 1980-2001.

Lukas, B. A., \& Maignan, I. (1996). Striving for quality: The key role of internal and external customers. Journal of Market-Focused Management, 1(2), 175.

Mani, V. (2011). Analysis of employee engagement and its predictors. International Journal of Human Resource Studies, 1(2), 15.

Mansour, D., \& Barandas, H. (2017). High-tech entrepreneurial content marketing for business model innovation: A conceptual framework. Journal of Research in Interactive Marketing, 11(3), 296-311.

McCormick, D., \& Maalu, J. (2011). Innovation hubs and small and medium enterprises in Africa: Setting the policy agenda.

Miles, P., Lewis, G. K., Hall-Phillips, A., Morrish, S. C., Gilmore, A., \& Kasouf, C. J. (2015). The influence of entrepreneurial marketing processes and entrepreneurial self-efficacy on community vulnerability, risk, and resilience. Journal of Strategic Marketing, 24(1), 34-46.

Moreno, A. M., \& Casillas, J. C. (2008). Entrepreneurial Orientation and Growth of SMEs: A Causal Model. Entrepreneurship Theory and Practice, 32(3), 507-528.

Morris, M. H., Schindehutte, M., \& LaForge, R. W. (2002). Entrepreneurial Marketing: A Construct for Integrating Emerging Entrepreneurship and Marketing Perspectives. Journal of Marketing Theory and Practice, 10(4), 1-19.

Morrish. (2009). Portfolio entrepreneurs: an effectuation approach to multiple venture development. Journal of Research in Marketing and Entrepreneurship, 11(1), 32-48.

Morrish, S. C. (2011). Entrepreneurial marketing: a strategy for the twenty-first century? Journal of Research in Marketing and Entrepreneurship, 13(2), 110119.

Morrish, S. C., \& Deacon, J. H. (2011). A Tale of Two Spirits: Entrepreneurial Marketing at 42Below Vodka and Penderyn Whisky. Journal of Small Business \& Entrepreneurship, 24(1), 113-124. 
Morrish, S. C., \& Jones, R. (2020). Post-disaster business recovery: An entrepreneurial marketing perspective. Journal of Business Research, 113, 83-92.

Morrish, S. C., Miles, M. P., \& Deacon, J. H. (2010). Entrepreneurial marketing: acknowledging the entrepreneur and customer-centric interrelationship. Journal of Strategic Marketing, 18(4), 303-316.

Mort, G. S., Weerawardena, J., \& Liesch, P. (2012). Advancing entrepreneurial marketing: Evidence from born global firms. European Journal of Marketing, $46(3-4), 542-561$.

Najafi-Tavani, S., Najafi-Tavani, Z., Naudé, P., Oghazi, P., \& Zeynaloo, E. (2018). How collaborative innovation networks affect new product performance: Product innovation capability, process innovation capability, and absorptive capacity. Industrial Marketing Management, 73, 193-205.

Narver, J. C., \& Slater, S. F. (1990). The Effect of a Market Orientation on Business Profitability. Journal of Marketing, 54(4), 20-35.

Ndubisi, N. O., \& Ndubisi, G. C. (2013). Sustainable Internal Marketing and Internal Customer Motivation Model: An African Small- and Medium-sized Enterprise Perspective. Journal of Asian and African Studies, 48(4), 521-538.

Oduro, S., \& Nyarku, K. M. (2018). Incremental Innovations in Ghanaian SMEs: Prope-nsity, Types, Performance and Management Challenges. Asia-Pacific Journal of Management Research and Innovation, 14(1-2), 10-21.

OECD. (2005). Oslo manual: guidelines for collecting and interpreting innovation data (3rd ed.). Organisation for Economic Co-operation and Development.

OECD. (2010). OECD Studies on SMEs and Entrepreneurship High-Growth Enterprises: What Governments Can Do to Make a Difference (1. Aufl. ed.). OECD Paris.

Owusu-Frimpong, N., \& Martins, A. (2010). Adoption and Implementation of Internal Marketing Systems by Ghanaian Small- and Medium-Sized Enterprises. Journal of African Business, 11(1), 26-48.

Özdemir, Ö. G. (2013). Entrepreneurial marketing and social value creation in Turkish art industry: An ambidextrous perspective. Journal of Research in Marketing and Entrepreneurship, 15(1), 39-60.

Pane Haden, S. S., Kernek, C. R., \& Toombs, L. A. (2016). The entrepreneurial marketing of Trumpet Records. Journal of Research in Marketing and Entrepreneurship, 18(1), 109-126.

Raisch, S., Birkinshaw, J., Probst, G., \& Tushman, M. L. (2009). Organizational Ambidexterity: Balancing Exploitation and Exploration for Sustained Performance. Organization Science, 20(4), 685-695. 
Rashad, N. M. (2018). The impact of entrepreneurial marketing dimensions on the organizational performance within Saudi SMEs. Eurasian Journal of Business and Management 6(3), 61-71.

Sadiku-Dushi, N., Dana, L.-P., \& Ramadani, V. (2019). Entrepreneurial marketing dimensions and SMEs performance. Journal of Business Research, 100, 86-99. Sarasvathy, S. D. (2001). Causation and Effectuation: Toward a Theoretical Shift from Economic Inevitability to Entrepreneurial Contingency. The Academy of Management Review, 26(2), 243-263.

Sasser, W. E., \& Arbeit, S. P. (1976). Selling jobs in the service sector. Business Horizons, 19(3), 61-65.

Scarborough, N. M., \& Cornwall, J. R. (2011). Essentials of entrepreneurship and small business management. Pearson London.

Shaw, E. (2004). Marketing in the social enterprise context: is it entrepreneurial? Qualitative Market Research: An International Journal, 7(3), 194-205.

Solé, M., \& Jones, R. (2013). Entrepreneurial marketing: conceptual exploration and link to performance. Journal of Research in Marketing and Entrepreneurship, 15(1), 23-38.

Sulistyo, H., \& Siyamtinah. (2016). Innovation capability of SMEs through entrepreneurship, marketing capability, relational capital and empowerment. Asia Pacific Management Review, 21(4), 196-203.

Tajeddini, K. (2011). Customer Orientation, Learning Orientation, and New Service Development: An Empirical Investigation of the Swiss Hotel Industry. Journal of Hospitality \& Tourism Research, 35(4), 437-468.

Tarraço, E. L., Bernardes, R. C., Borini, F. M., \& Rossetto, D. E. (2019). Innovation capabilities for global R\&D projects in subsidiaries. European Journal of Innovation Management, 22(4), 639-659.

Vargo, S. L., \& Lusch, R. F. (2010). From repeat patronage to value co-creation in service ecosystems: a transcending conceptualization of relationship. Journal of Business Market Management, 4(4), 169-179.

Whalen, P., Uslay, C., Pascal, V. J., Omura, G., McAuley, A., Kasouf, C. J., Jones, R., Hultman, C. M., Hills, G. E., Hansen, D. J., Gilmore, A., Giglierano, J., Eggers, F., \& Deacon, J. (2015). Anatomy of competitive advantage: towards a contingency theory of entrepreneurial marketing. Journal of Strategic Marketing, 24(1), 5-19.

Winter, J. P. (1985). Getting your house in order with internal marketing: a marketing prerequisite. Health marketing quarterly, 3(1), 69. 
Wu, W. Y., Tsai, C. C., \& Fu, C. S. (2013). The Relationships among Internal Marketing, Job Satisfaction, Relationship Marketing, Customer Orientation, and Organizational Performance: An Empirical Study of TFT-LCD Companies in Taiwan. Human Factors and Ergonomics in Manufacturing \& Service Industries, 23(5), 436-449.

Yadav, A., \& Bansal, S. (2020). Viewing marketing through entrepreneurial mindset: a systematic review. International Journal of Emerging Markets, ahead-of$\operatorname{print}($ ahead-of-print).

\section{BIOGRAPHCAL SKETCH OF AUTHORS}

Daniel Gameti is a $\mathrm{PhD}$ candidate in the Department of Management, Marketing and Entrepreneurship, University of Canterbury. His research is focused on Entrepreneurial Marketing, Innovation and SME Growth. Prior to his PhD studies, he was a lecturer at Ghana Institute of Management and Public Administration (GIMPA). His teaching and research interests are in Entrepreneurship, Marketing, Innovation, Service Management and Corporate Social Responsibility. Daniel holds M.Phil and B.Sc. Degrees in Business Administration from University of Ghana and University of Cape Coast respectively.

Jamie D. Collins is Professor and University Chair of Strategy, Innovation \& Entrepreneurship at University of Canterbury where he teaches post-graduate courses. He also holds Professorial Fellow status at Clemson University. He earned his Ph.D. from Texas A\&M University. Jamie's research examines the influence that perceptions of entrepreneurs and strategic leaders exert on their deliberate choices to invest organizational resources in the pursuit of innovation opportunities, in various institutional contexts.

Sussie C. Morrish is Professor of Marketing at the University of Canterbury Business School where she earned her PhD. She has previously taught at the University of Auckland Business School. Sussie teaches strategic marketing and entrepreneurship. Her main research interests revolve around the marketing and entrepreneurship interface including various strategic approaches to postdisaster business recovery, internationalisation, sustainability and entrepreneurial ecosystems. 